\title{
Genotype Dependence of Hepatitis C Virus Antibodies Detectable by the First-Generation Enzyme-linked Immunosorbent Assay with C100-3 Protein
}

\author{
Ryozo Nagayama, * Fumio Tsuda, " Hiroaki Okamoto, "Yu Wang," Takehiro Mitsui," \\ Takeshi Tanaka, ** Yuzo Miyakawa, ${ }^{\star *}$ and Makoto Mayumi" \\ ${ }^{*}$ The First Department of Internal Medicine, Teikyo University School of Medicine, Tokyo 173; ' ${ }^{\ddagger}$ the Viral Hepatitis Research \\ Foundation of Japan, Tokyo 113; §Immunology Division, Jichi Medical School, Tochigi-Ken 329-04, Japan; "Institute of Hepatology, \\ Beijing Medical University, Beijing, China; 'Masuko Memorial Hospital and Masuko Institute for Medical Research, Aichi-Ken 453; \\ ** Japanese Red Cross Blood Center, Saitama-Ken 338; and ${ }^{\ddagger}$ Mita Institute, Tokyo 108, Japan
}

\begin{abstract}
Hepatitis $\mathrm{C}$ virus (HCV) samples in 155 sera, from patients with chronic non-A, non-B liver disease and blood donors, were grouped into four genotypes (I, II, III, and IV) by amplification of core-gene sequences by polymerase chain reaction with typespecific primers. HCV genotypes were compared with various HCV-associated antibodies detectable by the first-generation ELISA (ELISA-1) with C100-3 protein and a second-generation immunoblot assay with four recombinant $\mathrm{HCV}$ proteins. Antibodies to $\mathbf{C 1 0 0 - 3}$ protein and those to its subsequence (5$1-1)$ were detected in $13(93 \%)$ and $12(86 \%)$, respectively, of 14 sera with genotype I HCV; 56 (79\%) and $58(82 \%)$ of 71 sera with genotype II; $13(34 \%)$ and $6(16 \%)$ of 38 sera with genotype III; and $11(34 \%)$ and $4(13 \%)$ of 32 sera with genotype IV. Amino acid sequences of C100-3 of genotype I HCV are conserved by $\sim 90 \%$ in genotype II, but only by $\sim 75 \%$ in genotypes III and IV. The sensitivity of ELISA-1, therefore, would be influenced by heterogeneity in $\mathrm{C100-3}$ sequences of different genotypes. (J. Clin. Invest. 1993. 92:1529-1533.) Key words: hepatitis $C$ virus • genotype • hepatitis antibodies • enzyme-linked immunosorbent assay $\bullet$ polymerase chain reaction
\end{abstract}

\section{Introduction}

The discovery of hepatitis C virus ( HCV $)^{1}$ by Choo et al. ( 1 ) is the major breakthrough in the research of non-A, non-B (NANB) hepatitis. HCV is a positive-stranded RNA virus of $\sim 9,400$ nucleotides with a 5'-noncoding region of $\sim 341 \mathrm{nu}-$ cleotides and a single open reading frame consisting of the core and envelope genes as well as nonstructural (NS) regions (2). The genomic sequence of HCV has been applied most practically to immunoassays for the detection of antibodies raised by hosts in response to $\mathrm{HCV}$ infection (3).

Address correspondence to Dr. M. Mayumi, Immunology Division, Jichi Medical School, Minamikawachi-Machi Tochigi-Ken 329-04, Japan.

Received for publication 23 December 1992 and in revised form 29 April 1993.

1. Abbreviations used in this paper: aa, amino acid; ALT, alanine aminotransferase; $\mathrm{HCV}$, hepatitis C virus; NANB, non-A, non-B; NS, nonstructural; PCR, polymerase chain reaction.

J. Clin. Invest.

(c) The American Society for Clinical Investigation, Inc. 0021-9738/93/09/1529/05 \$2.00

Volume 92, September 1993, 1529-1533
Serological diagnosis of $\mathrm{HCV}$ infection is a prerequisite to treatment and prevention of hepatitis $\mathrm{C}$ with a known preponderance for chronicity and serious sequelae ranging to hepatocellular carcinoma $(4,5)$. The first-generation ELISA (ELISA$1)$, using a recombinant fusion protein ( $\mathrm{C} 100-3)$ deduced from NS3 and NS4 regions (3), has been useful in detecting $\mathrm{HCV}$ infection in patients with acute and chronic NANB liver disease $(3,4)$ and in screening blood units for the prevention of post-transfusion NANB hepatitis (6-8).

The $\mathrm{C} 100-3$ protein used in ELISA- 1 is deduced from the nucleotide sequence of the prototype HCV (HCV-1 [9]). During the past few years, the entire nucleotide sequence was determined on a number of $\mathrm{HCV}$ isolates from different regions of the world. They can be grouped, by similarity in nucleotide sequence, into four genotypes provisionally designated I, II, III, and IV $(10,11)$. The prototype HCV (HCV-1 [9]) belongs to genotype I.

HCV samples in 155 sera from patients with chronic NANB liver disease and blood donors were genotyped, and $\mathrm{HCV}$-associated antibodies in them were tested for by ELISA-1 and a second-generation recombinant immunoblot assay (RIBA-2) involving four recombinant $\mathrm{HCV}$ proteins. Then, the sensitivity of antibodies to $\mathrm{C100-3}$ and its subsequence (51-1), in detecting viremia, was correlated with each of four different genotypes of $\mathrm{HCV}$.

\section{Methods}

Sera containing $H C V R N A$. Sera from patients with chronic NANB liver disease, hemophiliacs with liver function abnormalities, and blood donors were screened for antibody to a synthetic HCV core peptide (anti-CP10) by ELISA (12), and those with $\mathrm{A}_{492}$ values $\geqq 1.00$ were tested for HCV RNA by polymerase chain reaction (PCR). There were 155 sera with HCV RNA, including 41 from patients with chronic NANB hepatitis, 26 from patients with primary hepatocellular carcinoma, 10 from hemophiliacs, and 78 from donors of whom 18 were with alanine aminotransferase (ALT) levels $>45 \mathrm{IU} /$ liter.

$\mathrm{HCV}$-associated antibodies. Antibodies to $\mathrm{C100-3}$ protein were determined by ELISA-1 (Ortho Diagnostic Systems, Tokyo, Japan), and sera with $\mathrm{A}_{492}$ values $>0.450$ were considered reactive. Antibodies to four recombinant $\mathrm{HCV}$ proteins were determined by RIBA-2 (Ortho) with C100-3 deduced from NS3 and NS4 regions corresponding to amino acid (aa) 1569-1931, 5-1-1 representing its subsequence (aa 1694-1735), C33c (NS3 region, aa 1192-1457), and C22-3 (the putative core gene, aa 2-120); they all were deduced from the nucleotide sequence of the prototype HCV of genotype I [HCV-1 (9)].

Anti-CP10 was determined as previously described (12). Briefly, CP10 (19-mer) with a sequence of Pro-Lys-Pro-Gln-Arg-Lys-Thr-LysArg-Asn-Thr-Asn-Arg-Arg-Pro-Gln-Asp-Val-Lys ( aa 5-23 of the putative core protein ) was synthesized chemically, which was deduced from HC-J1 (genotype I) and HC-J4 (genotype II) isolates (13). Wells of an immunoplate were coated with CP10 $(250 \mathrm{ng} / \mathrm{ml}$ in $10 \mathrm{mM}$ phosphate 
buffer, $\mathrm{pH} 7.5$ ), and overcoated with buffer supplemented with $40 \%$ ( $\mathrm{vol} / \mathrm{vol}$ ) bovine serum. Wells received $10 \mu \mathrm{l}$ of test serum and $50 \mu \mathrm{l}$ of specimen diluent [saline supplemented with $40 \%$ ( $\mathrm{vol} / \mathrm{vol}$ ) bovine serum and $0.05 \%$ ( $\mathrm{vol} / \mathrm{vol}$ ) Tween 20 ], and the plate was incubated at room temperature for $1 \mathrm{~h}$. Bound antibodies were detected with mouse monoclonal antibody against human IgG $/ \gamma$ labeled with horseradish peroxidase. Sera with $A_{492}$ values $>0.30$, which were inhibited by $>50 \%$ in the presence of $\mathrm{CP} 10(50 \mu \mathrm{g} / \mathrm{ml})$, were considered reactive.

Detection of HCV RNA and genotyping. RNA was extracted from 1 $\mathrm{ml}$ of serum, reverse transcribed, and amplified by a two-stage PCR with nested primers deduced from the 5 '-noncoding region of the HCV genome (14). Antisense primer in the original method (no. 36), for cDNA synthesis and the first stage of PCR, was replaced by no. 299 with a sequence of 5'-ACCCAACACTACTCGGCTAG-3' representing nucleotides $250-269$ in the 5'-noncoding region (13). The modified PCR amplified a product of $225 \mathrm{bp}$ with a sensitivity comparable with that of the original method.

Four genotypes of HCV, designated I, II, III, and IV $(10,11)$, were determined by amplification of HCV RNA with a universal primer (sense) and the mixture of four type-specific primers that were deduced from comparison of the putative core-gene sequences of $44 \mathrm{HCV}$ isolates (10). The primer specific for genotype I (no. 132) was replaced by no. 296 with a sequence of 5'-GGATAGGCTGACGTCTACCT-3' representing nucleotides 518-539 of the putative core gene. The size of PCR product with primer no. 296 was $49 \mathrm{bp}$, compared with $57 \mathrm{bp}$ in the original method. Products of PCR amplification were run on electrophoresis, stained with ethidium bromide, and observed under ultraviolet light. Genotypes were judged by the size of products: $49 \mathrm{bp}$ for genotype I, $144 \mathrm{bp}$ for genotype II, $174 \mathrm{bp}$ for genotype III, and $123 \mathrm{bp}$ for genotype IV.

Statistical analysis. Frequencies were compared using Fisher's exact probability test or the $\chi^{2}$ test.

\section{Results}

Table I compares the frequency of various $\mathrm{HCV}$-associated antibodies, detectable by ELISA-1 or RIBA-2, in 155 sera with $\mathrm{HCV}$ of four different genotypes. Antibodies to $\mathrm{C100-3}$ protein were detected by ELISA-1 or RIBA-2 in $13(93 \%)$ of 14 sera with genotype I HCV and in $56(79 \%)$ of 71 with genotype II, more frequently than in $13(34 \%)$ of 38 with genotype III or in $11(34 \%)$ of 32 with genotype IV $(P<0.001)$. Similarly, antibodies to 5-1-1 protein, representing a subsequence of C100-3, were detected in $12(86 \%)$ sera with genotype I HCV and 58 $(82 \%)$ with genotype II, more often than in $6(16 \%)$ with genotype III and $4(13 \%)$ with genotype IV $(P<0.001)$.

By contrast, antibodies to $\mathrm{C} 33 \mathrm{c}$ or $\mathrm{C} 22-3$ protein were detected in all 155 sera with HCV RNA, irrespective of genotypes. These sera had been selected by anti-CP10 ELISA with a synthetic core peptide (12), and they all were positive with $A_{492}$ values $\geqq 1.00$.

Table II compares the detection of antibodies to C100-3 and 5-1-1 in blood donors with normal or elevated transaminase levels and in patients with chronic NANB liver disease, all of whom were infected with $\mathrm{HCV}$ of genotypes other than I. They were divided into two groups, one with HCV of genotype II and the other with HCV of genotype III or IV. Antibodies to C100-3 and 5-1-1 were detected less frequently in blood donors with normal ALT levels than in donors with elevated ALT ( $P$ $<0.01)$ or in patients $(P<0.001)$, all of whom were infected with HCV of genotype II. Similarly, the detection of these antibodies was influenced by the clinical status of hosts infected with HCV of genotype III or IV; antibody to C100-3 was detected most hardly in donors with normal ALT levels.

Four representative HCV isolates of different genotypes were compared within amino acid sequences of the four antigen probes used in ELISA-1 and RIBA-2 (Table III). The sequence of C100-3 protein, deduced from genotype I HCV (HCV-1 [9]), is conserved by almost $90 \%$ in genotype II (HCV-BK [15]), but only by $\sim 75 \%$ in genotype III (HC-J6 [16]) or IV (HC-J8 [11]). Variations dependent on genotypes are much greater in the sequence of $5-1-1$; it is conserved by $83 \%$ in genotype II $\mathrm{HCV}$, but only by $\sim 50 \%$ in genotype III or IV.

In Fig. 1, the maximal number of discordance within every 10 amino acids, among HCV isolates of four different genotypes, is plotted along the sequence of $\mathrm{C100-3}$ protein. Considerable variations dependent on genotypes are scattered over the C100-3 sequence, and 5-1-1 protein falls on an area of the highest variation.

The sequence of $\mathrm{C} 33 \mathrm{c}$ is well conserved among $\mathrm{HCV}$ isolates of four different genotypes, with a similarity of $>83 \%$ (Table III). The sequence of C22-3 is the most preserved of the four antigen probes, with a similarity of $>89 \%$ among them. The sequence of CP10 is highly conserved also, 17 (89\%) of 19 amino acids being identical in $\mathrm{HCV}$ isolates of four different genotypes $(9,11,14,15)$.

\section{Discussion}

Although ELISA-1 with the recombinant $\mathrm{C} 100-3$ protein has established a undisputable impact on the diagnosis and prevention of HCV infection, it is not without flaws. ELISA-1 is not very sensitive, missing viremia in some blood units that could transmit HCV infection to recipients (6-8) or in sera in which HCV RNA was detected by PCR (17). ELISA-1 is not specific,

Table 1. HCV-associated Antibodies Detectable by ELISA-1 or RIBA-2 in Sera with HCV of Four Different Genotypes

\begin{tabular}{|c|c|c|c|c|c|c|}
\hline \multirow[b]{2}{*}{ Genotype of HCV } & \multirow[b]{2}{*}{$n$} & \multirow{2}{*}{$\begin{array}{c}\text { ELISA-1* } \\
\text { (anti-C100-3) }\end{array}$} & \multicolumn{4}{|c|}{ Detection by RIBA-2 of antibodies to ${ }^{\dagger}$} \\
\hline & & & $\mathrm{C} 100-3^{\dagger}$ & $5-1-1$ & $\mathrm{C} 33 \mathrm{c}$ & $\mathrm{C} 22-3$ \\
\hline I & 14 & $13(93 \%)$ & $13(93 \%)$ & $12(86 \%)$ & $14(100 \%)$ & $14(100 \%)$ \\
\hline II & 71 & $56(79 \%)$ & $55(77 \%)$ & $58(82 \%)$ & $71(100 \%)$ & $71(100 \%)$ \\
\hline III & 38 & $13(34 \%)$ & $13(34 \%)$ & $6(16 \%)$ & $38(100 \%)$ & $38(100 \%)$ \\
\hline IV & 32 & $11(34 \%)$ & $9(28 \%)$ & $4(13 \%)$ & $32(100 \%)$ & $32(100 \%)$ \\
\hline
\end{tabular}

\footnotetext{
* Antibodies to C100-3 protein, deduced from the prototype HCV genome (HCV-1 [9]) of genotype I, was determined by the first-generation enzyme immunoassay (Ortho). ${ }^{\dagger}$ Antibodies to four $\mathrm{HCV}$ proteins, deduced from various regions of the prototype HCV genome (HCV-1 [9]) of genotype I, were detected by a second-generation recombinant immunoblot assay (Ortho).
} 
Table II. Detection of Antibodies to C100-3 and 5-1-1 in Blood Donors and Patients with HCV of Genotype II, III, or IV*

\begin{tabular}{|c|c|c|c|c|c|}
\hline \multirow[b]{2}{*}{$\begin{array}{l}\text { Infection } \\
\text { with HCV of: }\end{array}$} & \multirow{2}{*}{$\begin{array}{l}\text { Origin of } \\
\text { sera }\end{array}$} & \multirow[b]{2}{*}{$n$} & \multirow{2}{*}{$\begin{array}{c}\text { ELISA-1 } \\
\text { (anti-C100-3) }\end{array}$} & \multicolumn{2}{|c|}{ RIBA-2 } \\
\hline & & & & $\mathrm{Cl} 100-3$ & $5-1-1$ \\
\hline \multirow[t]{3}{*}{ Genotype II } & Donors $(\mathrm{ALT} \leqq 45)$ & 30 & $16(53 \%)$ & $15(50 \%)$ & $19(63 \%)$ \\
\hline & Donors $(\mathrm{ALT}>45)$ & 12 & $12(100 \%)$ & $12(90 \%)$ & $11(92 \%)$ \\
\hline & Patients & 29 & $28(97 \%)$ & $28(97 \%)$ & $29(100 \%)$ \\
\hline \multirow[t]{3}{*}{ Genotype III or IV } & Donors (ALT $\leqq 45)$ & 26 & $3(12 \%)$ & $3(12 \%)$ & $3(12 \%)$ \\
\hline & Donors (ALT > 45) & 6 & $2(33 \%)$ & $2(33 \%)$ & $0(0 \%)$ \\
\hline & Patients & 38 & $19(50 \%)$ & $17(45 \%)$ & $7(18 \%)$ \\
\hline
\end{tabular}

* Detectability of anti-C100-3 by ELISA-1 and RIBA-2, as well as antibody to 5-1-1 by RIBA-2, was compared in blood donors and patients with chronic NANB liver disease who were infected with HCV of genotypes other than I. Donors were divided into two groups with normal ( $\leqq 45$ IU/liter) or elevated ALT levels (>45 IU/liter).

either, testing falsely positive in some sera with high levels of IgG, typically in those from patients with autoimmune chronic active hepatitis (18). Antibodies to superoxide dismutase, making a part of the antigen probe, were implicated in false positivity in some sera (19).

As a confirmatory test for ELISA-1, the first-generation recombinant immunoblot assay (RIBA-1) has been introduced (20), which involves the binding of immunoglobulins to $\mathrm{C} 100$ 3 protein and its subsequence (5-1-1), as well as superoxide dismutase, fixed on nitrocellulose strips. Reactivity with both C100-3 and 5-1-1 is interpreted as confirmatory for ELISA-1 and that with superoxide dismutase alone as false positive.

Both ELISA-1 and RIBA- 1 use C100-3, as well as its subsequence (5-1-1), which is deduced from the prototype HCV [HCV-1 (9)]. Being an RNA virus that is evolving rapidly (21), HCV variants are expected to occur that would have a good deal of sequence divergence. This proved to be the case for $\mathrm{HCV}$ isolates, which have been sequenced partially or along the entire genome. To date, the entire nucleotide sequence is determined for $\mathrm{HCV}$ isolates of four genotypes, which differ from each other by $>21 \%$ in the entire nucleotide sequence, and they are provisionally designated genotypes I, II, III, and IV $(10,11)$. On the basis of sequence similarities, genotypes I and II are closely related, as are genotypes III and IV (11).

Table III. Comparison of Amino Acid Sequences of Antigen Probes Used in ELISA-1 and RIBA-2 among HCV Isolates of Different Genotypes*

\begin{tabular}{lcrrr}
\hline & $\begin{array}{c}\text { Amino acids } \\
\text { in comparison } \\
\text { Antigen } \\
\text { probes }\end{array}$ & $n$ (position $\left.^{\dagger}\right)$ & \multicolumn{3}{c}{$\begin{array}{c}\text { Numbers of amino acids of an HCV isolate of } \\
\text { genotype I shared by HCV isolates of }\end{array}$} \\
\cline { 3 - 6 } & Genotype II & Genotype III & Genotype IV \\
\hline C100-3 & $363(1569-1931)$ & $324(89.3 \%)$ & $278(76.6 \%)$ & $271(74.7 \%)$ \\
$5-1-1$ & $42(1694-1735)$ & $35(83.3 \%)$ & $22(52.4 \%)$ & $21(50.0 \%)$ \\
C33c & $266(1192-1457)$ & $245(92.1 \%)$ & $223(83.8 \%)$ & $224(84.2 \%)$ \\
C22-3 & $119(2-120)$ & $116(97.5 \%)$ & $106(89.1 \%)$ & $108(90.8 \%)$
\end{tabular}

* Amino acid sequences of antigen probes used in ELISA-1 and RIBA-2, deduced from the nucleotide sequence of an HCV isolate of genotype I (HCV-1 [9], the prototype HCV) are compared with those deduced from HCV isolates of genotype II (HCV-BK [15]), III (HC-J6 [16]), or IV (HC-J8 [11]). ${ }^{\dagger}$ Amino acid positions are numbered in accordance with those of the prototype $\mathrm{HCV}$ genome (HCV-1 [9]).
Genotype-dependent variations are not evenly distributed over the entire genome. The 5'-noncoding region of $\sim 341$ nucleotides is best conserved with a similarity of $>92 \%$ among $\mathrm{HCV}$ isolates of different genotypes, and therefore, would be ideal for use as primers in PCR for a sensitive detection of HCV RNA $(14,22,23)$. Variations in nucleotide and deduced amino acid sequences are much greater within the coding region of $\mathrm{HCV}$, which is divided into core and envelope genes and five nonstructural regions (NS1-NS5).

The sequence of C100-3, coded for by NS3 and NS4 regions, is very variable among $\mathrm{HCV}$ isolates of four genotypes, and 5-1-1 falls on an area of extensive variation within it (Fig. 1). Genotype-dependent sequence diversities were faithfully reflected on the sensitivity of ELISA-1 and RIBA-2 in detecting antibodies to C100-3 and 5-1-1 (Table II). Reasonably, these assays were most sensitive in detecting antibodies raised in the infection with $\mathrm{HCV}$ of genotype I. The sensitivity was somewhat lower for antibodies in the infection with genotype II $\mathrm{HCV}$, but reasonably high at $80 \%$; it was much lower in the infection with genotype III or IV at $34 \%$ for antibodies to $\mathrm{C} 100$ 3 and 13-16\% for antibodies to 5-1-1. Genotype dependence of antibodies to C100-3 and 5-1-1 has been pointed out by others also $(2,24)$, and they would be responsible for a limited performance of ELISA-1 in detecting viremia.

Among those infected with HCV of genotypes other than I, antibodies to C100-3 and 5-1-1 were detected in blood donors with normal transaminase levels less sensitively than in donors with elevated transaminase levels or in patients with chronic NANB liver disease. Detectability of these antibodies would depend on the intensity of immune responses to HCV antigens, which might be involved in the pathogenesis of NANB hepatitis.

The efficacy of ELISA-1 in decreasing the incidence of posttransfusion hepatitis $C$ varies widely depending on countries where it was evaluated. In Spain (6), the efficacy is $56 \%$, much lower than $84 \%$ in the United States (7). The efficacy in Japan is in between at $73 \%(8)$. HCV of genotype I prevails in the United States $(2,11)$, where the prototype HCV has been propagated (9), while genotype II is most common in the Far East, being determined in 131 (82\%) of 159 blood donors with viremia in Japan (10). These observations are in agreement with good performance of ELISA-1 in these two countries. A poor performance in Spain may indicate that HCV of genotypes other than I or II would be more common there than in the United States and Japan. 


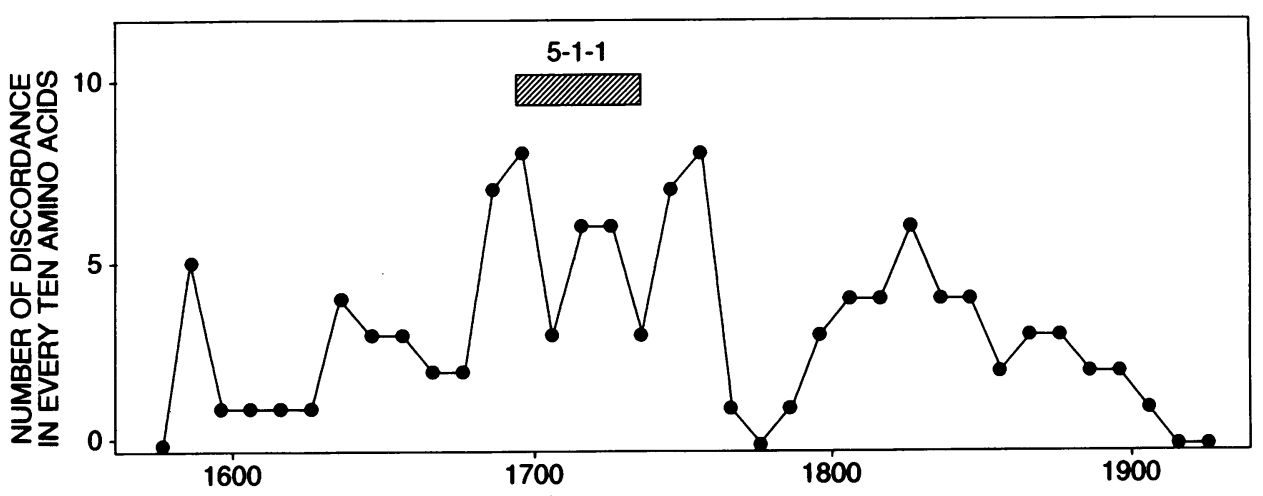

AMINO ACID POSITIONS IN C100-3 PROTEIN (1569-1931)
Figure 1. Variations in the amino acid sequence of $\mathrm{Cl} 100-3$ protein among four HCV isolates of different genotypes. The sequence of C100-3 protein spanning aa 1569 1931 was divided into 36 sections, each with 10 aa (the last 3 aa ignored). The number of maximal discordance among four $\mathrm{HCV}$ isolates of different genotypes, within every $10 \mathrm{aa}$, is plotted. HCV isolates in comparison are HCV-1 of genotype I (9), HCV-BK of genotype II (15), HC-J6 of genotype III (16), and HC-J8 of genotype IV (11). The position of 5-1-1 protein (1694$1735)$ is indicated by the shaded bar.
Recently, RIBA-2 was introduced, which uses, in addition to $\mathrm{C} 100-3$ and 5-1-1, C33c protein encoded by the NS3 region and $\mathrm{C} 22-3$ protein by the putative core gene (25). Superb sensitivity and specificity of RIBA-2 were extended to ELISA-2, which has gained an instantaneous popularity in the diagnosis of HCV infection in clinical and epidemiological settings.

Among $\mathrm{HCV}$ isolates of four different genotypes, the amino acid sequences of $\mathrm{C} 33 \mathrm{c}$ and $\mathrm{C} 22-3$ are more conserved than that of $\mathrm{C} 100-3$ or 5-1-1 (Table III). C33c and C22-3 blots in RIBA-2 are reported to be more sensitive than $\mathrm{C} 100-3$ or 5-1-1 blot in identifying sera contaminated with HCV (26). Marvelously, antibodies to C33c and C22-3 were detected in all 155 sera with viremia in the present study. Hence, an advantage is obvious for employing antigen probes whose sequences are conserved by HCV of any genotypes. In actuality, ELISA$2 s$ involving conserved sequences have expanded the power of diagnosing $\mathrm{HCV}$ infection; $90-98 \%$ of patients with chronic NANB liver disease possess antibodies detectable by ELISAs with the HCV core protein or its sequences (27).

Even ELISA-2 is not flawless in the detection of hepatitis C viremia (28), however. There still remains a residual risk of developing posttransfusion hepatitis $\mathrm{C}$ in recipients of blood units screened by ELISA-2 $(28,29)$. A third-generation ELISA may yet be developed, with additional conserved sequences bearing immunodominant epitopes, which will be delineated by comparison of many $\mathrm{HCV}$ isolates with different genotypes from all over the world. It would have to cope with infections with HCV of still other genotypes. Recently, HCV isolates are reported from Edinburgh (30) and Thailand (31), partial sequences of which differ substantially from those of genotypes I-IV, and they could be classified as genotypes V and VI, respectively.

Unfortunately, protective immunity is weak or lacking in chimpanzees with experimental HCV infection, allowing reinfection to occur even by the same HCV inoculum used in the initial transmission $(32,33)$. There may still be a long way before prophylactic measures are taken by hepatitis $C$ vaccines. In the interim, we may work towards further improvements in ELISA for infallible detection of hepatitis $\mathrm{C}$ viremia.

\section{References}

1. Choo, Q.-L., G. Kuo, A. J. Weiner, L. R. Overby, D. W. Bradley, and M. Houghton. 1989. Isolation of a cDNA clone derived from a blood-borne non-A, non-B viral hepatitis genome. Science (Wash. DC). 244:359-362.
2. Houghton, M., A. Weiner, J. Han, G. Kuo, and Q. L. Choo. 1991. Molecular biology of the hepatitis $\mathrm{C}$ viruses: implications for diagnosis, development and control of viral disease. Hepatology. 14:381-388.

3. Kuo, G., Q.-L. Choo, H. J. Alter, G. L. Gitnick, A. G. Redeker, R. H. Purcell, T. Miyamura, J. L. Dienstag, M. J. Alter, C. E. Stevens, et al. 1989. An assay for circulating antibodies to a major etiologic virus of human non-A, non-B hepatitis. Science (Wash. DC). 244:362-364.

4. Alter, H. J., R. H. Purcell, J. W. Shih, J. C. Melpolder, M. Houghton, Q.-L. Choo, and G. Kuo. 1989. Detection of antibody to hepatitis C virus in prospectively followed transfusion recipients with acute and chronic non-A, non-B hepatitis. N. Engl. J. Med. 321:1494-1500.

5. Dienstag, J. L. 1983. Non-A, non-B hepatitis. I. Recognition, epidemiology, and clinical features. Gastroenterology. 85:439-462.

6. Esteban, J. I., A. González, J. M. Hernández, L. Viladomiu, C. Sánchez, J. C. Lopez-Talavera, D. Lucea, C. Martin-Vega, X. Vidal, R. Esteban, et al. 1990. Evaluation of antibodies to hepatitis $C$ virus in a study of transfusion-associated hepatitis. N. Engl. J. Med. 323:1107-1112.

7. Donahue, J. G., A. Muñoz, P. M. Ness, D. E. Brown, D. H. Yawn, H. A. McAllister, B. A. Reitz, and K. E. Nelson. 1992. The declining risk of post-transfusion hepatitis C virus infection. N. Engl. J. Med. 327:369-373.

8. Japanese Red Cross Non-A, Non-B Hepatitis Research Group. 1991. Effect of screening for hepatitis $C$ virus antibody and hepatitis $B$ virus core antibody on incidence of post-transfusion hepatitis. Lancet. 338:1040-1041.

9. Choo, Q.-L., K. H. Richman, J. H. Han, K. Berger, C. Lee, C. Dong, C. Gallegos, D. Coit, A. Medina-Selby, P. J. Barr, et al. 1991. Genetic organization and diversity of the hepatitis C virus. Proc. Natl. Acad. Sci. USA. 88:2451-2455. 10. Okamoto, H., Y. Sugiyama, S. Okada, K. Kurai, Y. Akahane, Y. Sugai, T. Tanaka, K. Sato, F. Tsuda, Y. Miyakawa, et al. 1992. Typing hepatitis C virus by polymerase chain reaction with type-specific primers: application to clinical surveys and tracing infectious sources. J. Gen. Virol. 73:673-679.

11. Okamoto, H., K. Kurai, S. Okada, K. Yamamoto, H. lizuka, T. Tanaka, S. Fukuda, F. Tsuda, and S. Mishiro. 1992. Full-length sequence of a hepatitis C virus genome having poor homology to reported isolates: comparative study of four distinct genotypes. Virology. 188:331-341.

12. Okamoto, H., F. Tsuda, A. Machida, E. Munekata, Y. Akahane, Y. Sugai, K. Mashiko, T. Mitsui, T. Tanaka, Y. Miyakawa, et al. 1992. Antibodies against synthetic oligopeptides deduced from the putative core gene for the diagnosis of hepatitis C virus infection. Hepatology. 15:180-186.

13. Okamoto, H., S. Okada, Y. Sugiyama, S. Yotsumoto, T. Tanaka, H. Yoshizawa, F. Tsuda, Y. Miyakawa, and M. Mayumi. 1990. The 5'-terminal sequence of the hepatitis C virus genome. Jpn. J. Exp. Med. 60:167-177.

14. Okamoto, H., S. Okada, Y. Sugiyama, T. Tanaka, Y. Sugai, Y. Akahane, A. Machida, S. Mishiro, H. Yoshizawa, Y. Miyakawa, et al. 1990. Detection of hepatitis C virus RNA by a two-stage polymerase chain reaction with two pairs of primers deduced from the 5'-noncoding region. Jpn. J. Exp. Med. 60:215-222.

15. Takamizawa, A., C. Mori, I. Fuke, S. Manabe, S. Murakami, J. Fujita, E. Onishi, T. Andoh, I. Yoshida, and H. Okayama. 1991. Structure and organization of the hepatitis $\mathrm{C}$ virus genome isolated from human carriers. J. Virol. 65:1105-1113.

16. Okamoto, H., S. Okada, Y. Sugiyama, K. Kurai, H. lizuka, A. Machida, Y. Miyakawa, and M. Mayumi. 1991. Nucleotide sequence of the genomic RNA of hepatitis $\mathrm{C}$ virus isolated from a human carrier: comparison with reported isolates for conserved and divergent regions. J. Gen. Virol. 72:2697-2704.

17. Weiner, A. J., G. Kuo, D. W. Bradley, F. Bonino, G. Saracco, C. Lee, J. Rosenblatt, Q.-L. Choo, and M. Houghton. 1990. Detection of hepatitis C viral sequences in non-A, non-B hepatitis. Lancet. 335:1-3.

18. McFarlane, I. G., H. M. Smith, P. J. Johnson, G. P. Bray, D. Vergani, and 
R. Williams. 1990. Hepatitis C virus antibodies in chronic active hepatitis: pathogenetic factor or false-positive result? Lancet. 335:754-757.

19. Ikeda, Y., G. Toda, N. Hashimoto, and K. Kurokawa. 1990. Antibody to superoxide dismutase, autoimmune hepatitis, and antibody tests for hepatitis C virus. Lancet. 335:1345-1346.

20. Ebeling, F., R. Naukkarinen, and J. Leikola. 1990. Recombinant immuno blot assay for hepatitis $\mathrm{C}$ virus antibody as predictor of infectivity. Lancet. 335:982-983.

21. Holland, J., K. Spindler, F. Horodyski, E. Grabau, S. Nichol, and S. VandePol. 1982. Rapid evolution of RNA genomes. Science (Wash. DC). 215:1577-1585.

22. Cha, T.-A., J. Kolberg, B. Irvine, M. Stempien, E. Beall, M. Yano, Q.-L. Choo, M. Houghton, G. Kuo, J. H. Han, et al. 1991. Use of a signature nucleotide sequence of hepatitis $\mathrm{C}$ virus for detection of viral RNA in human serum and plasma. J. Clin. Microbiol. 29:2528-2534.

23. Bukh, J., R. H. Purcell, and R. H. Miller. 1992. Importance of primer selection for the detection of hepatitis $C$ virus RNA with the polymerase chain reaction assay. Proc. Natl. Acad. Sci. USA. 89:187-191.

24. Chan, S.-W., P. Simmonds, F. McOmish, P. L. Yap, R. Mitchell, B. Dow, and E. Follett. 1991. Serological responses to infection with three different types of hepatitis C virus. Lancet. 338:1391.

25. van der Poel, C. L., H. T. M. Cuypers, H. W. Reesink, A. J. Weiner, S. Quan, R. di Nello, J. J. P. van Boven, I. Winkel, D. Mulder-Folkerts, P. J. ExelOehlers, et al. 1991. Confirmation of hepatitis $C$ virus infection by new four-antigen recombinant immunoblot assay. Lancet. 337:317-319.
26. McHutchison, J. G., J. L. Person, S. Govindarajan, B. Valinluck, T. Gore S. R. Lee, M. Nelles, A. Polito, D. Chien, R. DiNello, et al. 1992. Improved detection of hepatitis $\mathrm{C}$ virus antibodies in high-risk populations. Hepatology. 15:19-25.

27. Alter, H. J. 1992. New kit on the block: evaluation of second-generation assays for detection of antibody to the hepatitis C virus. Hepatology. 15:350-353.

28. Sugitani, M., G. Inchauspé, M. Shindo, and A. M. Prince. 1992. Sensitivity of serological assays to identify blood donors with hepatitis C viraemia. Lancet. 339:1018-1019.

29. Aach, R. D., C. E. Stevens, F. B. Hollinger, J. W. Mosley, D. A. Peterson, P. E. Taylor, R. G. Johnson, L. H. Barbosa, and G. J. Nemo. 1991. Hepatitis C virus infection in post-transfusion hepatitis. An analysis with first- and secondgeneration assays. N. Engl. J. Med. 325:1325-1329.

30. Chan, S.-W., F. McOmish, E. C. Holmes, B. Dow, J. F. Peutherer, E Follett, P. L. Yap, and P. Simmonds. 1992. Analysis of a new hepatitis C virus type and its phylogenetic relationship to existing variants. J. Gen. Virol. 73:11311141.

31. Mori, S., N. Kato, A. Yagyu, T. Tanaka, Y. Ikeda, B. Petchclai, P. Chiewsilp, T. Kurimura, and K. Shimotohno. 1992. A new type of hepatitis $\mathrm{C}$ virus in patients in Thailand. Biochem. Biophys. Res. Commun. 183:334-342.

32. Prince, A. M., B. Brotman, T. Huima, D. Pascual, M. Jaffery, and G. Inchauspé. 1992. Immunity in hepatitis C infection. J. Infect. Dis. 165:438-443.

33. Farci, P., H. J. Alter, S. Govindarajan, D. C. Wong, R. Engle, R. R. Lesniewski, I. K. Mushahwar, S. M. Desai, R. H. Miller, N. Ogata, et al. 1992. Lack of protective immunity against reinfection with hepatitis $\mathrm{C}$ virus. Science (Wash. DC). 258:135-140. 